\section{Climate and landscape response}

SIR - That an increase in regional elevation could have promoted global cooling during the Late Cenozoic is one of several proposed mechanisms that may have contributed to the initiation of extensive Pleistocene glaciation. Molnar and England have pointed out ${ }^{1}$ that the validity of this model, which has regained some favour ${ }^{2}$, depends on the reality of Late Cenozoic surface uplift. They also argue that the Late Cenozoic climate changes which such apparent uplift is thought to explain, could themselves "cause the same changes in the landscape and fossil record as regional uplift would". Although we acknowledge that it is important to be aware of circular arguments in attempting to establish lines of cause and effect in complex environmental systems, Molnar and England fail to justify their assertion that Late Cenozoic climate change and surface uplift could elicit an equivalent geomorphological response at the regional scale.

Can increases in denudation rates brought about by climate change cause rapid incision of high plateaus and the formation of precipitous mountain relief? Molnar and England assume that the onset of glaciation necessarily leads to a significant increase in denudation rates, yet they provide no evidence in support of this crucial component of their hypothesis. None of the three reports on the relationship between climate and sediment yield that they cite considers glacial regimes in detail (and none allows adequately for the effects of local relief). The limited data that are available in fact indicate that denudation rates in glaciated catchments are broadly comparable to those in non-glaciated basins with similar local relief and precipitation. Indeed, maximum erosion rates appear to be associated with maximum precipitation rather than the proportion of a basin that is glaciated ${ }^{3}$.

We are unconvinced as to the impact of the increase in 'storminess' on denudation rates conjectured in ref. 1 , even if such a climate change did occur in the Late Cenozoic. Although there is

1. Motnar, P. \& England, P. Nature 346, 29-34 (1990). 2. Ruddiman, W. F. \& Raymo, M. E. Phil. Trans. R. Soc B318, 411-430 (1988).

3. Hicks, D. M., McSaveney, M. J. \& Chinn, T. J. H. Arct. Álp. res. 22, 26-42 (1990)

4. Ahnert, F. Am. J. Sci. 268, 243-263 (1970)

5. Embleton, C. \& King, C. A. M. Glacial Geomorphology (Edward Arnold, London, 1975)

6. Drewry, D. Glacial Geologic Processes (Edward Arnold, London, 1986)

7. Harbor, J. M., Hallet, B. \& Raymond, C. F. Nature 333 347-349 (1988)

8. Wahrhaftig, C. \& Cox, A. Geol. Soc. Am. Bull. 70 383-436 (1959)

9. Church, M. \& Slaymaker, O. Nature 337, 452 (1989).

10. Meade, R. H. Geol. Soc. Am. Bull. 80, 1265 (1969).

11. Trimble, S. W. Science 188, 1207-1208 (1975); Am J. Sci. 265, 876-887 (1977).

2. Church, M. \& Ryder, J. M. Geol. Soc. Am. Bull. 83 , 3072-3095 (1972). abundant evidence that the magnitudefrequency characteristics of runoff can significantly affect rates of sediment transport, at least where sediment availability is adequate, studies of present sediment and solute yield also demonstrate that local relief exerts a critical control over denudation rates ${ }^{4}$. An increase in local relief, and consequently stream-channel and hill-slope gradients, in response to tectonic uplift should have a much greater impact on denudation rates than a change to a stormier climate, the more so because the associated increase in elevation will also promote more orographic precipitation.

Department of Geography

M. A. SUMMERFIELD

University of Edinburgh,

Edinburgh EH8 9XP, UK

M. P. KIRKBRIDE

Department of Geography,

University of Dundee,

Dundee DD1 $4 \mathrm{HN}$, UK

MOLNAR AND ENGLAND REPLY - We suggested $^{1}$ that the various processes that created the evidence commonly used to infer recent uplift of mountain ranges could have been induced by climate change. Summerfield and Kirkbride take issue with the suggestion that climate change could affect the processes controlling rates and styles of erosion in the same way and to the degree that uplift presumably can. They can make two points: the first we consider to be minor, but the other reveals a very different perspective on how to examine what is important.

Their first comment, about glacial erosion, exaggerates what we wrote. Like others $^{5-8}$, we do suspect that alpine glacial erosion is rapid, and therefore that in the past few million years it may have been more rapid at high elevations than other forms of erosion were earlier. Uncertainties as to whether or not glacial erosion has been rapid, however, do not negate the suggestion that climate change has played a major role in creating the many landforms, glacial and non-glacial, commonly used to infer recent uplift of mountain ranges.

Underlying their second objection, concerning denudation rates, is the widely held belief that 'juvenile topography' implies recent uplift. It is reasonable to assume that abrupt uplift of terrains above the base levels of their drainage systems should cause increases in erosion rates, denudation rates and relief. The commonly made, converse step of inferring recent uplift from the existence of high relief, however, depends on the assumption that only uplift of the terrain can cause the erosive and denudational processes to increase. Perhaps this assumption is correct, but to demonstrate its validity requires a quantitative understanding of the processes that cause erosion and sediment transport and of the factors that affect these processes, not simply an observed correlation followed by an assertion about cause and effect.

To buttress the claim that rapid denudation is the result to uplift, Summerfield and Kirkbride cite the well known correlation $^{4}$ of relief with high sediment yield, which when scaled by the area of the drainage basins is called the 'denudation rate'. Again, we question Summerfield and Kirkbride's assignments of cause to uplift and of effect to rapid denudation drawn from this correlation. First, the use of sediment transport as a surrogate for denudation rates has been discouraged repeatedly, except in those studies (such as ref. 9) designed specifically to understand the processes that govern both denudation and sediment transport. Meade ${ }^{10}$ and Trimble ${ }^{11}$ have shown clearly how the alteration of the landscape by humans has made sediment transport a very misleading measure of denudation. Church and Ryder ${ }^{12}$ deduced that much of the sediment transported by rivers through glacially excavated regions was actually eroded by the glaciers and was subsequently stored in the basins for thousands of years. Thus, such 'denudation rates' may give very misleading measures of both current and Late Cenozoic rates of denudation.

Second, what is the evidence or logic that makes the assertion that "local relief exerts a critical control over denudation rates" more defensible than, for instance, that high local relief is a consequence of rapid sediment transport? More importantly, the commonly made assignment of the cause of rapid sediment transport to a state, high relief, shifts the focus of scientific investigation away from the study of the processes by which erosion occurs and sediment is transported. Without understanding these processes, we cannot predict quantitatively how either climate change or uplift might cause an increase in erosion rates or relief.

We certainly do not presume that tectonic processes have played no role in creating relief, but we insist that what is known about geomorphological processes permits climate change to be the cause of the 'juvenile topography' and rapid sediment transport that have commonly been attributed to recent uplift.

PETER MOLNAR

Department of Earth, Atmospheric and

Planetary Sciences,

Massachusetts Institute of Technology,

Cambridge, Massachusetts 02139, USA

PHILIP ENGLAND

Department of Earth Sciences,

University of Oxford, Oxford OX1 3PR, UK 